\title{
Coastal oceanic climate change and variability from 1982 to 2009 around South Africa
}

\author{
M Rouault ${ }^{1 *}$, B Pohl² and P Penven ${ }^{3}$ \\ ${ }_{1}^{1}$ Department of Oceanography, Marine Research Institute, University of Cape Town, Rondebosch 7701, South Africa \\ ${ }^{2}$ Centre de Recherches de Climatologie, CNRS / Université de Bourgogne, 6 boulevard Gabriel, 21000 Dijon, France \\ ${ }^{3}$ Laboratoire de Physique des Oceans, UBO, IRD and IFREMER, 29280 Plouzané, France \\ *Corresponding author, e-mail: mathieu.rouault@uct.ac.za
}

\begin{abstract}
Changes and fluctuations in sea surface temperature (SST) around the South African coast are analysed at a monthly scale from 1982 to 2009 . There is a statistically significant negative trend of up to $0.5{ }^{\circ} \mathrm{C}$ per decade in the southern Benguela from January to August, and a cooling trend of lesser magnitude along the South Coast and in the Port Elizabeth/Port Alfred region from May to August. The cooling is due to an increase in upwellingfavourable south-easterly and easterly winds. There is a positive trend in SST of up to $0.55{ }^{\circ} \mathrm{C}$ per decade in most parts of the Agulhas Current system during all months of the year, except for KwaZulu-Natal where warming is in summer. The warming was attrib-uted to an intensification of the Agulhas Current in response to a poleward shift of westerly winds and an increase in trade winds in the South Indian Ocean at relevant latitudes. This intensification of the Agulhas Current could also have contributed to the coastal cooling in the Port Alfred dynamic upwelling region. The EI Niño Southern Oscillation (ENSO) is significantly positively correlated at a 95\% level with the southern Benguela and South Coast from February to May, and negatively correlated with the Agulhas Current system south of $36^{\circ} \mathrm{S}$. The correlation with the Antarctic Annular Oscillation is weaker and less coherent. El Niño suppresses upwelling along the coast, whereas La Niña increases it. Although there does not seem to be a linear relationship between the strength of the ENSO and the magnitude of coastal SST perturbation, EI Niño and La Niña appear to be linked to major warm and cool events, respectively, at a seasonal scale in summer in the southern Benguela and along the South Coast. However, care must be taken in interpreting lowresolution reanalysed climate data (ERA40 and NCEP) and optimally interpolated Reynolds SST, such as used here.
\end{abstract}

Keywords: Agulhas Current, Benguela upwelling, climate change, ENSO, Southern Annular Mode

Introduction

The Intergovernmental Panel on Climate Change (IPCC 2007) confirmed the anthropogenic footprint on global land and sea surface temperature (SST). Questions remain, though, about future climate at a regional scale in a world where $\mathrm{CO}_{2}$, methane and other gases continue to rise and to what extent anthropogenic climate change has already taken place at a regional scale. The subject is complicated because an anthropogenic effect is superimposed on natural climate variability. For instance, a change in the Pacific since the mid-1970s (Trenberth 1990) and a related global climate shift does not seem to have been stimulated by an anthropogenic effect, but it did have a huge impact on world climate. Interannual changes in Pacific Ocean SST modify the weather pattern worldwide and have a strong impact on southern African summer rainfall and associated atmospheric circulation (Fauchereau et al. 2003, 2009, Pohl et al. 2009, 2010).

Regionally, the El Niño Southern Oscillation (ENSO) influences SST in the South Atlantic (Colberg et al. 2004).
The relationship between the ENSO and southern African rainfall is not linear, but the correlation between rainfall anomalies and SST in the Pacific is statistically significant (Fauchereau et al. 2003), notably so since the 1970 s (Richard et al. 2000, 2001). Most of the severe droughts have happened during the mature phase of El Niño and the wettest summers during La Niña (Rouault and Richard 2003, 2005). At an interannual time-scale, the Antarctic Annular Oscillation (AAO) has an influence on South Africa's Western Cape rainfall in winter (Reason and Rouault 2005). The AAO, sometimes referred to as the Southern Annular Mode (SAM), is the leading mode of atmospheric variability in the Southern Hemisphere high latitudes (Thompson and Wallace 2000). Mid-latitude westerly winds and the subtropical high-level jet tend to be shifted towards or away from the pole during opposite phases of the AAO. Change in the AAO from austral spring to autumn was linked to significant change in Marion Island climate by Rouault et al. (2005) for 
the period 1960-2000 owing to a poleward shift of westerly wind. Although a lot of research has dealt with the impact of ENSO on southern African summer rainfall (see Reason et al. 2006 for a review of recent work), less has been done to study the effect of ENSO on the coastal sea surface. Only Agenbag (1996) mentioned a potential influence of the 1992 El Niño event on abnormal warming in SST around the Cape Peninsula. Here, we use 28 years of satellite remote sensing estimates of SST and in situ observations to address the issue, by reanalysing climate datasets to relate changes to corresponding atmospheric conditions, and presenting 1982-2009 trends in SST and time-series of monthly anomalies for five coastal regions around South Africa and the Agulhas Current system south of $36^{\circ} \mathrm{S}$. The relationship between SST, ENSO and the AAO, i.e. two major modes of climate variability, is addressed. Observed changes in atmospheric condition are presented to explain the observed trends in SST. Finally, a word of caution is aired on the use of low resolution reanalysed climate and SST global data for regional analysis.

\section{Data}

We used $1^{\circ} \times 1^{\circ}$ resolution optimally interpolated SST (Reynolds SST; Reynolds et al. 2002). Reynolds SST is derived from daily merged, in situ, high-resolution $(9 \mathrm{~km})$ infrared satellite observations from the AVHRR (advanced very high resolution radiometer) instrument on board NOAA (National Oceanic and Atmospheric Administration) satellites. It has been used successfully in southern Africa to represent coastal SST, for instance in describing the 1999/2000 extreme oceanographic event in the southern Benguela (Roy et al. 2001) and Benguela Niños (Rouault et al. 2003a). Those successes were attributable to the offshore and alongshore extent of those severe perturbations. Rouault and Lutjeharms (2003) and Rouault et al. (2003b) showed that even if the Reynolds SST does not represent accurately all features of the Agulhas Current system or coastal area because of the resolution of the data and the interpolation scheme, it can be used satisfactorily when averaged over a large domain. National Center for Environmental Prediction (NCEP) reanalysis data (Kalnay et al. 1996) are used to assess circulation changes associated with ENSO and linear trends. Here, we utilise the NCEP data with a monthly time-resolution and a spatial resolution of $2.5^{\circ}$ latitude $\times 2.5^{\circ}$ longitude. Note that the spatial resolution of these reanalysed data does not resolve the upwelling region. However, for the purpose of analysing large-scale circulation anomalies over the South Atlantic-Africa-South Indian Ocean region, NCEP resolution is adequate. We use the AVISO (Archiving, Validation and Interpretation of Satellite Oceanographic data) mean dynamic topography (Rio et al. 2005) and associated data on mean geostrophic currents derived from altimetry, observations and a model. Rainfall was obtained from a $1^{\circ} \times 1^{\circ}$ resolution GPCC (Global Precipitation Climatology Center; Schneider et al. 2008) dataset derived from land observations.

\section{Results}

Figure 1 shows the domain used for the time-series analyses. The regions we studied were: (1) West Coast, (2) South Coast,

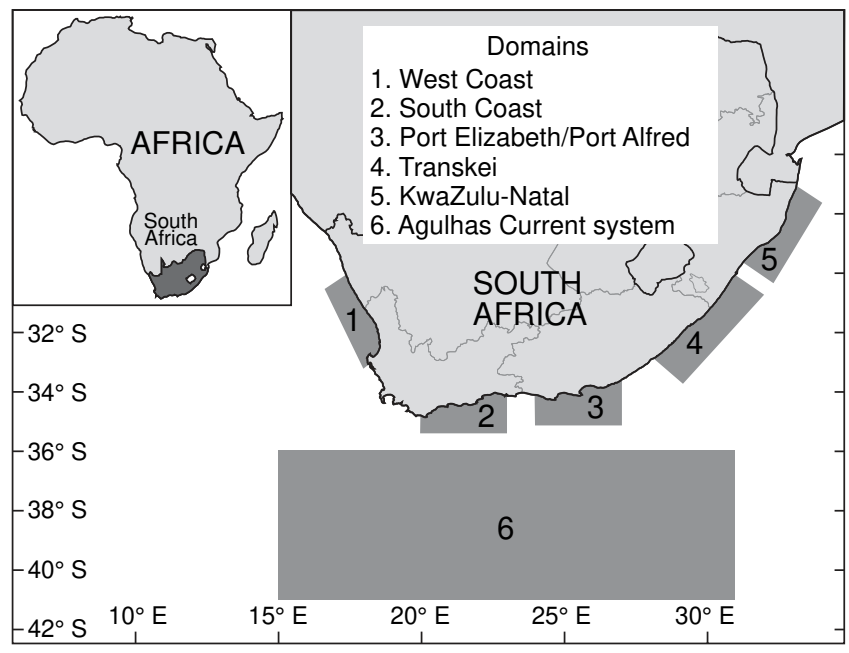

Figure 1: The domains used in the study. The Reynolds SST is averaged in each of the domains to construct monthly time-series, 1982-2009

(3) Port Elizabeth/Port Alfred, (4) Transkei and (5) KwaZuluNatal. Each coastal time-series is derived by averaging data in a domain $3^{\circ}$ wide along the coast and extending $1^{\circ}$ offshore, so that they have approximately the same size. We also used a region (6) encompassing the Agulhas Current system averaged from $36^{\circ}$ to $42^{\circ} \mathrm{S}$ and from $15^{\circ}$ to $30^{\circ} \mathrm{E}$. The Reynolds SST data use high-resolution morning and evening AVHRR satellite estimates and all available observations. Figure 2 shows the linear trend in SST using $1^{\circ} \times 1^{\circ}$ resolution Reynolds SST from 1982 to 2007 . Superimposed is the mean 1993-2007 absolute geostrophic current vector derived from merged altimetry (Rio et al. 2005). Figure 2 also shows the main features of the Agulhas Current system. The main loop is south of the continent, and the retroflection located in the domain delimited by the area $10^{\circ}-20^{\circ} \mathrm{E}$ and $37^{\circ}-42^{\circ} \mathrm{S}$. Eddies shed from the Agulhas Current are usually formed in the retroflection area and move mostly in a north-west direction towards Brazil. The Agulhas Return Current flows eastwards and meanders. The Agulhas Current system has warmed by up to $1.5^{\circ} \mathrm{C}$ since the 1980s, argued by Rouault et al. (2009) to have resulted from an intensification of the Agulhas Current system in response to an augmentation of wind-stress curl in the South Indian Ocean. The increase in the wind stress itself is attributable to an increase in trade winds and a poleward shift in the westerly wind at the relevant latitude.

A regional ocean model (Penven et al. 2006), able to reproduce the observed SST relatively well, was used to derive quantities such as transport, fluxes of heat and salt, and temperature trends at depth. It showed that the transport of the Agulhas Current system has increased since the 1980 s, leading to the warming. Coastal cooling of up to $0.55^{\circ} \mathrm{C}$ per decade is also apparent (Figure 2), mainly along South Africa's west coast. Changes have been of lesser magnitude along the South Coast (from Cape Agulhas to Cape St Francis), as well as in the dynamic upwelling cell around Port Elizabeth/Port Alfred. The cooling in the west of the country is continuous from Cape Agulhas to the Namibian 


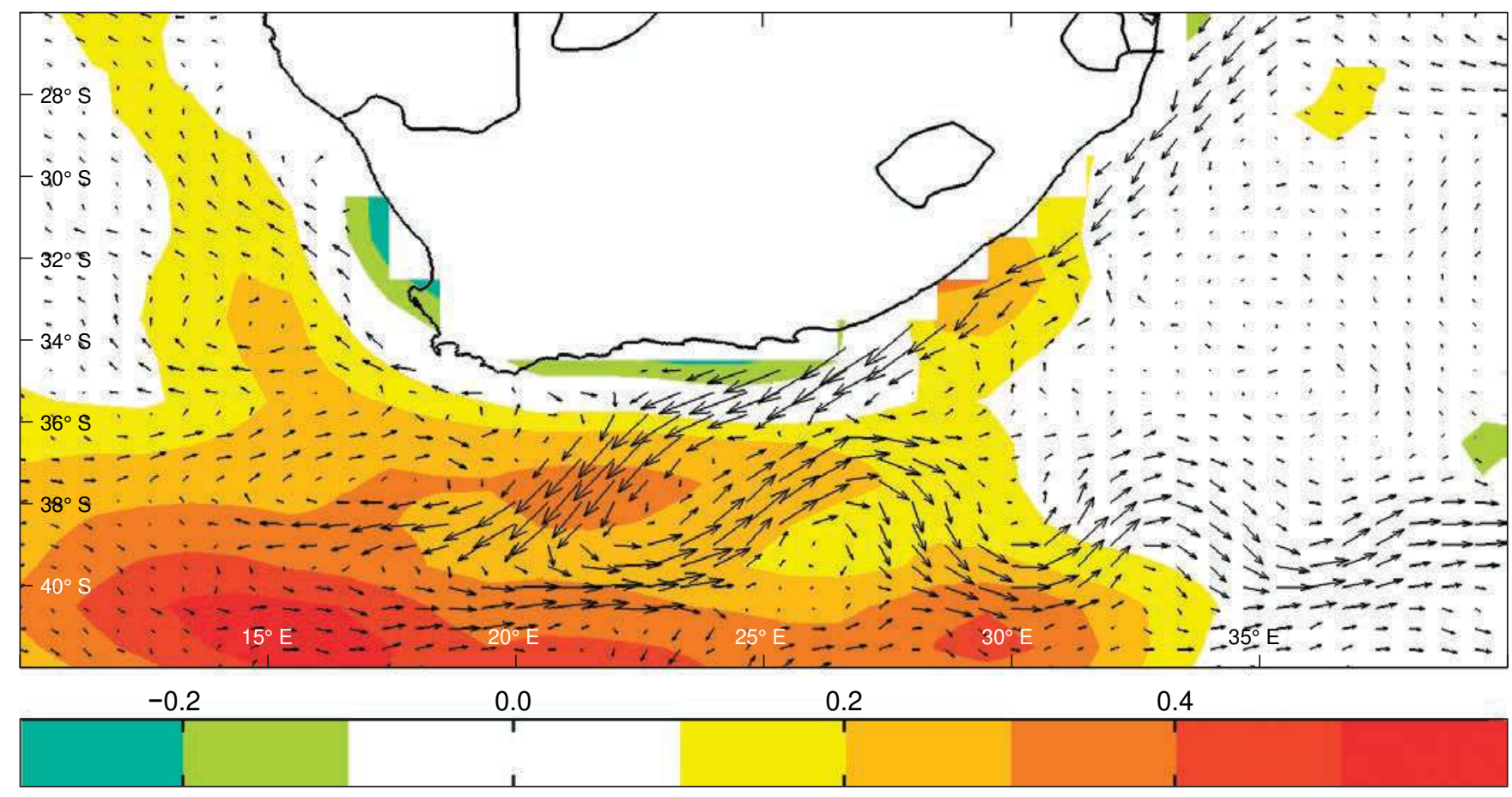

SST TREND $\left({ }^{\circ} \mathrm{C}\right.$ per decade)

Figure 2: Linear trend of $1^{\circ} \times 1^{\circ}$ resolution Reynolds SST, 1985-2009. Mean AVISO absolute geostrophic velocity vectors derived from the mean dynamic topography (Rio et al. 2005) are superimposed

border. The West Coast and South Coast cooling obtained with Reynolds SST are consistent with values obtained by Rouault et al. (2009) using yearly $4 \mathrm{~km}$ resolution AVHRR SST from 1985 to 2007 only, due to availability of data. Note that monthly mean of $4 \mathrm{~km}$ resolution AVHRR are not readily available and missing data due to clouds and sunglint makes its use problematic. Values obtained here for the cooling in the dynamic upwelling cell of Port Alfred and Port Elizabeth using Reynolds SST are underestimated when compared with those found by Rouault et al. (2009, Figure 1a) using $4 \mathrm{~km}$ resolution AVHRR, although from 1985 to 2007. This is due to the low resolution of the Reynolds SST and also because it is an interpolated product that makes use of the neighbouring cells when not enough AVHHR or observation data are available. Therefore, Reynolds SST probably does not allow capturing of the full intensity of the changes in the Port Alfred/Port Elizabeth region. Rouault et al. (2009) showed that this cooling is actually as strong as West Coast upwelling and spreads into the Agulhas Current itself and to the west. They argue that this could be the result of an intensification of the Agulhas Current that could have increased the dynamic upwelling and advected colder upwelled water offshore, although an increase in coastal upwelling-favourable winds could also be a factor (Rouault et al. 1995, 2000).

Next, we looked at SST linear trends in the five coastal regions around South Africa and in the Agulhas Current system. Figure 3 shows the 1982-2009 trends for all months of the year in the six regions defined. Although a bit short to study a trend, this series still represents changes over a 28-year period. There is a negative trend of up to $-0.55^{\circ} \mathrm{C}$ per decade for the West Coast from January to August, up to $-0.35^{\circ} \mathrm{C}$ per decade for the South Coast from May to August, and up to $-0.4{ }^{\circ} \mathrm{C}$ per decade for Port Elizabeth/ Port Alfred, mostly from May to August. There is no change for the months September-December for all three regions, and no change in summer for either the South Coast or Port Elizabeth/Port Alfred. A warming of up to $0.55^{\circ} \mathrm{C}$ per decade is observed in the Transkei domain and for the Agulhas Current for all months of the year, but little change in the KwaZulu-Natal domain except for a statistically significant trend of up to $0.25^{\circ} \mathrm{C}$ per decade from December to February. Change in the Agulhas Current system is more marked in the retroflection area itself, and decreases to the east (Figure 2). The winter change is the most robust signal across the region, with cooling for the West Coast, the South Coast and Port Elizabeth/Port Alfred, and warming for the Agulhas Current system to the south.

We then investigated interannual variability of the system using the monthly anomaly from the climatology. Monthly anomalies divided by the standard deviation for that month for the six regions are presented in Figure 4 for all regions to characterise abnormal events, as well as their strength and duration. Major events lasted a few months and started mainly in summer. There were major warm events in 1983, 1986, 1987, 1992, 1993, 1994, 2003 and 2007. Most of these were El Niño years. They were simultaneous in the West Coast, the South Coast and Port Elizabeth/Port Alfred, at various degrees of severity. Major cooling events were in 1989, 1996, 1997, 2000 and 2006, most of these being La Niña years. The 1992-1994 warming was during the protracted 1991-1995 El Niño event (Allan et al. 2003). The 


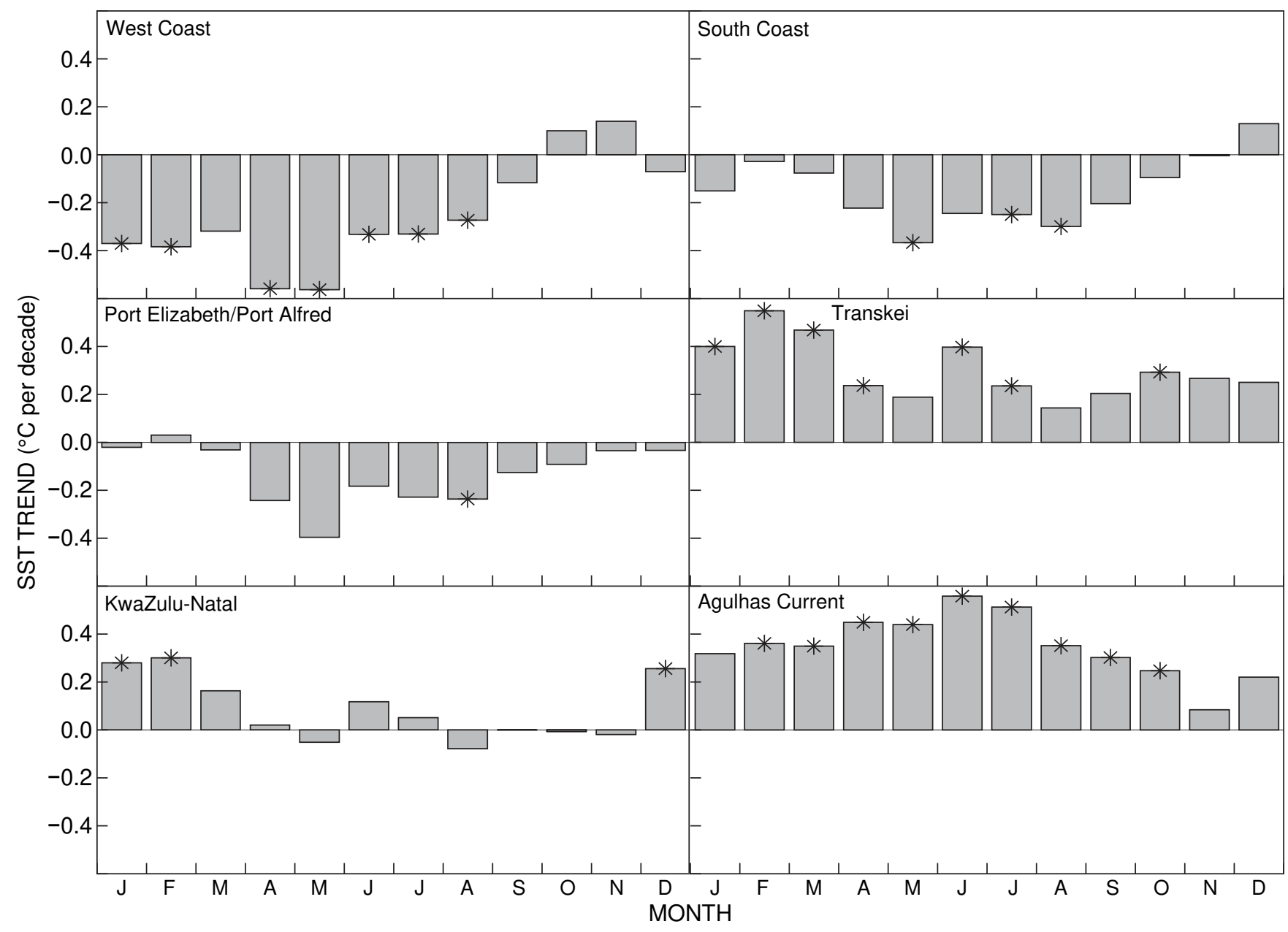

Figure 3: Linear trend in temperature per decade for each month of the year derived using the Reynolds SST, 1982-2009, for the West Coast, South Coast, Port Elizabeth/Port Alfred, Transkei, KwaZulu-Natal and the Agulhas Current system domains. Asterisks denote statistically significant trends at the $95 \%$ level according to Spearman's rank correlation

1997/1998 El Niño failed to create any substantial warming. We note too that there was no major rainfall or regional climate anomaly in summer 1997/1998, a strong El Niño year in South Africa (Rouault and Richard 2003, 2005).

The cross-correlation between monthly SST anomalies for the various regions is shown in Table 1. It confirms the common variability of the regions that was also present in SST trends and anomalies. Similar results are obtained with detrended data. SST anomalies at a monthly scale are positively and significantly correlated for the West Coast and the South Coast, the West Coast and Port Elizabeth/ Port Alfred, the South Coast and Port Elizabeth/Port Alfred, KwaZulu-Natal and Transkei, Transkei and the Agulhas Current system, and KwaZulu-Natal and the Agulhas Current system. The only adjacent regions not significantly correlated are Port Elizabeth/Port Alfred and Transkei but this could be due to the coarse resolution SST data used here. The Agulhas Current system and Transkei are negatively and significantly correlated with the West Coast. The correlation between the South Coast and the West Coast or between other adjacent domains can be attributed to a variety of factors, bearing in mind that all regions are dwarfed by the weather systems that affect them. Low-pressure systems move from west to east, generating north-westerly, westerly, and south-westerly winds, and connect all the regions. Likewise, high-pressure systems can influence several regions concurrently. For instance, during high-pressure conditions, strong south-easterly wind along the West Coast can occur concurrently with strong easterly wind along the South Coast or farther east. Prolonged periods with more or less of the above will suppress or favour upwelling, modify the net heat budget at the sea surface (i.e. latent and sensible heat fluxes and the radiative budget), and Ekman pumping. The latent and sensible heat fluxes are high in the Agulhas Current system, and the presence of clouds further reduces the short-wave radiative flux into the ocean (Rouault et al. 2000, 2003b). Remote forcing of a South Coast upwelling event through Kelvin waves generated during a West Coast upwelling event (Crépon and Richez 1982) could also be a factor.

Correlation with the ENSO using the multivariate ENSO index (MEI; Wolter and Timlin 1993) provided by the Climate Diagnostic Center (http://www.cdc.noaa.gov), along with SST anomalies of the six regions defined above, are presented for all months of the year in Figure 5. The MEI, 

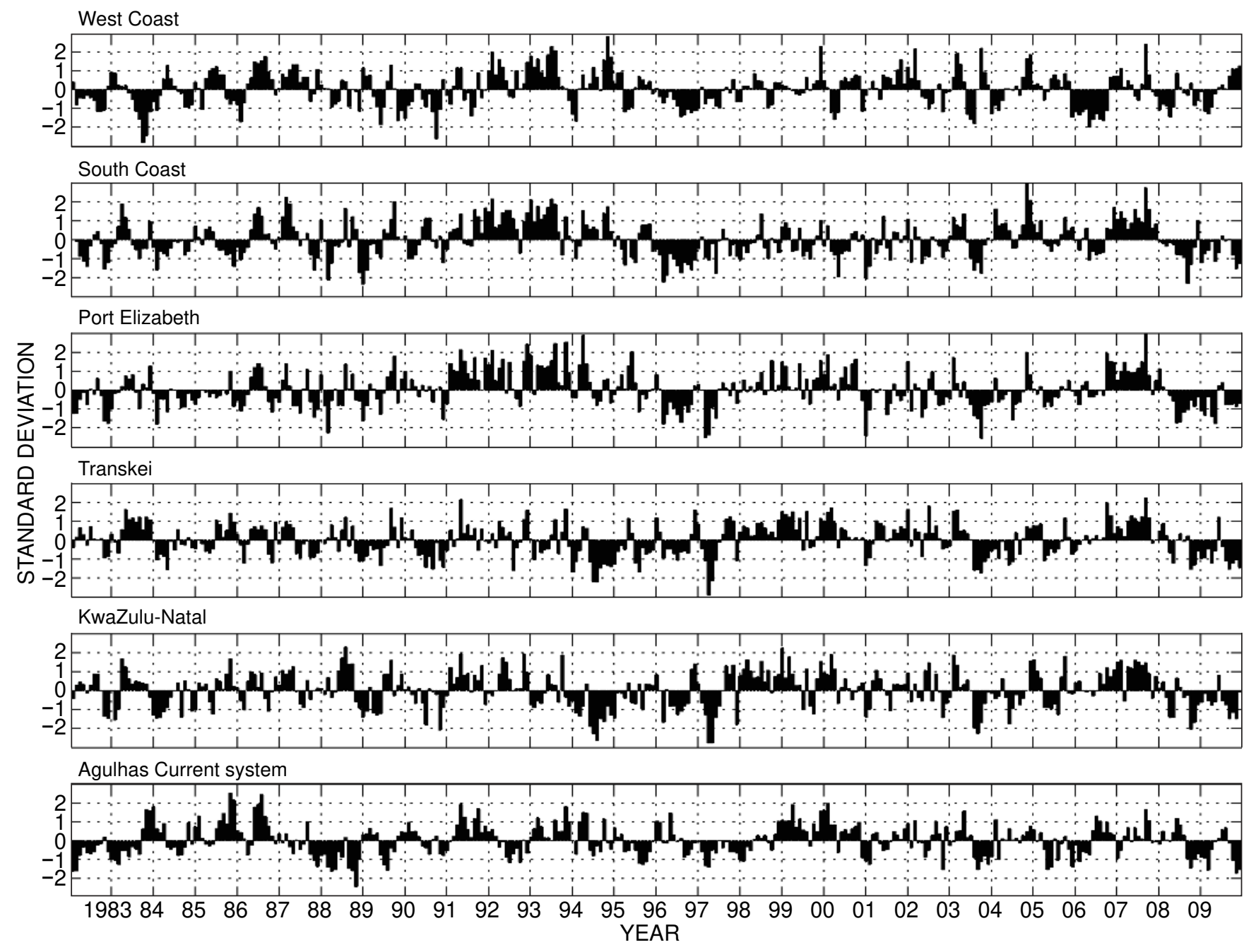

Figure 4: Detrended normalised anomaly from the monthly mean, 1982-2009, using the Reynolds SST for the West Coast, South Coast, Port Elizabeth/Port Alfred, Transkei, KwaZulu-Natal and Agulhas Current system $\left(36^{\circ}-42^{\circ} \mathrm{S}, 10^{\circ}-35^{\circ} \mathrm{E}\right)$

Table 1: Correlation between normalised anomalies SST of the six regions. Significant correlation at the $95 \%$ level is shown emboldened

\begin{tabular}{|c|c|c|c|c|c|c|}
\hline Domain & West Coast & South Coast & PE/PA & Transkei & KZN & Agulhas \\
\hline West Coast & 1.00 & 0.68 & 0.53 & -0.38 & -0.04 & -0.31 \\
\hline Port Elizabeth/Port Alfred & & & 1.00 & 0.10 & 0.36 & 0.08 \\
\hline KwaZulu-Natal & & & & & 1.00 & 0.31 \\
\hline Agulhas Current system & & & & & & 1.00 \\
\hline
\end{tabular}

based on both atmospheric and oceanic fields, describes the coupled nature of the ENSO phenomenon. The index does not show any trend towards more of an El Niño or a La Niña state. Significant correlation at a $95 \%$ level according to a Bravais-Pearson test is indicated with a dashed line. The correlation is significantly positive ( $E$ I Niños relate to warmerthan-normal SST, La Niña to cooler SST) mainly from February to May for the West Coast and the South Coast, but it could also be a factor in early summer. Correlation is not significant for Port Elizabeth/Port Alfred, but there are some indications of a modulation of SST by the ENSO during the same period of the year as for the West Coast and the South Coast. There is also a coherent negative correlation between the Agulhas Current system domain that is almost a mirror image of the correlation between the ENSO and the West Coast. There is no correlation for Transkei, and an opposite sign correlation in the KwaZulu-Natal domain. In Figure 6, anomalies from climatology for the means of February, March and April are plotted from 1982 to 2008 for the West Coast. There is a clear indication that most, but not all, warm events relate to El Niño and most cold ones to $L a$ Niña. Figure 6 indicates that there is no linear relationship 


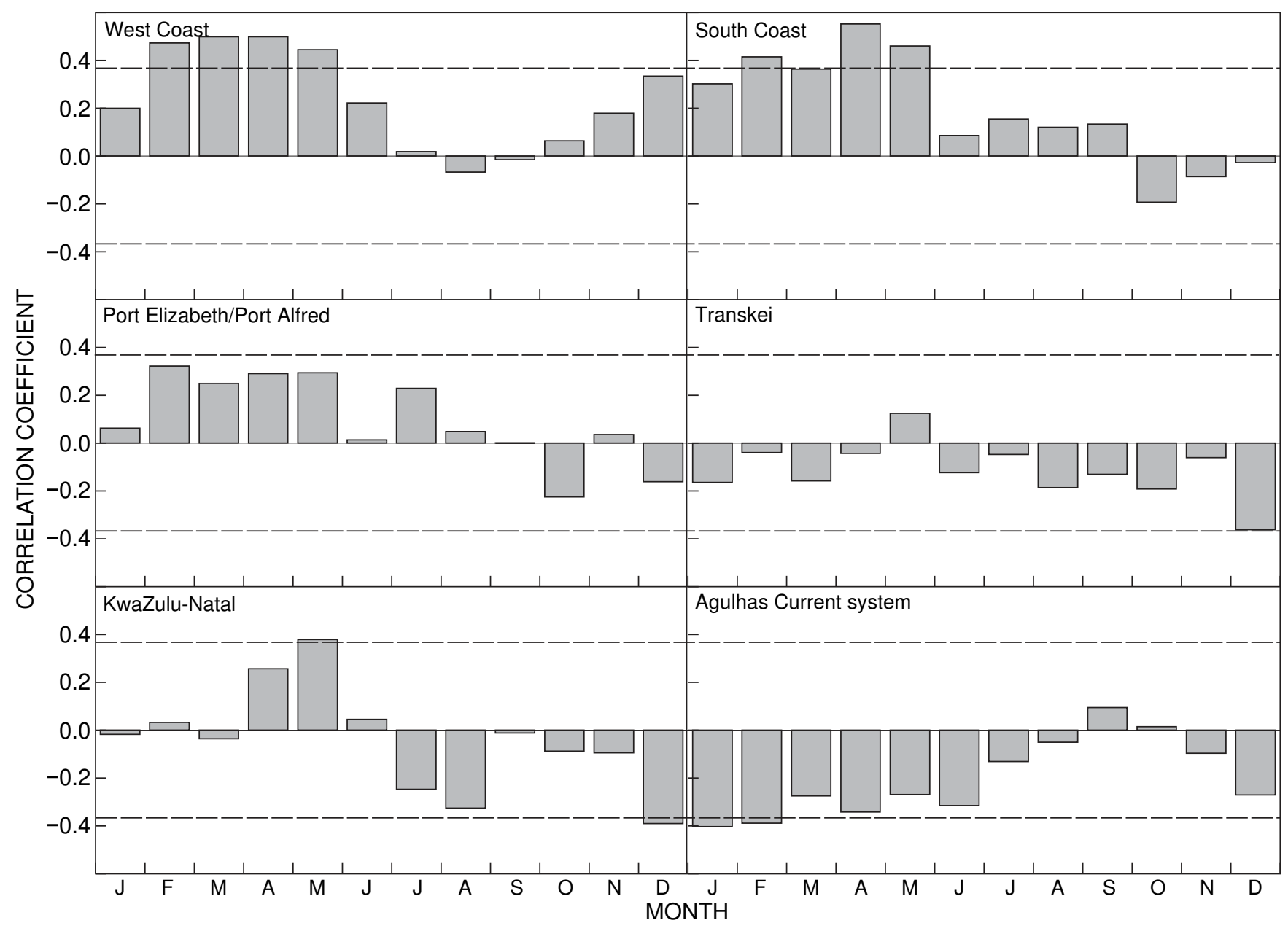

Figure 5: Correlation between the ENSO (MEI index) and the Reynolds SST normalised anomalies for the West Coast, South Coast, Port Elizabeth/Port Alfred, Transkei, KwaZulu-Natal and the Agulhas Current system ( $36^{\circ}-42^{\circ} \mathrm{S}$ and from $\left.10^{\circ}-35^{\circ} \mathrm{E}\right)$. Statistically significant correlations are marked with dashed lines

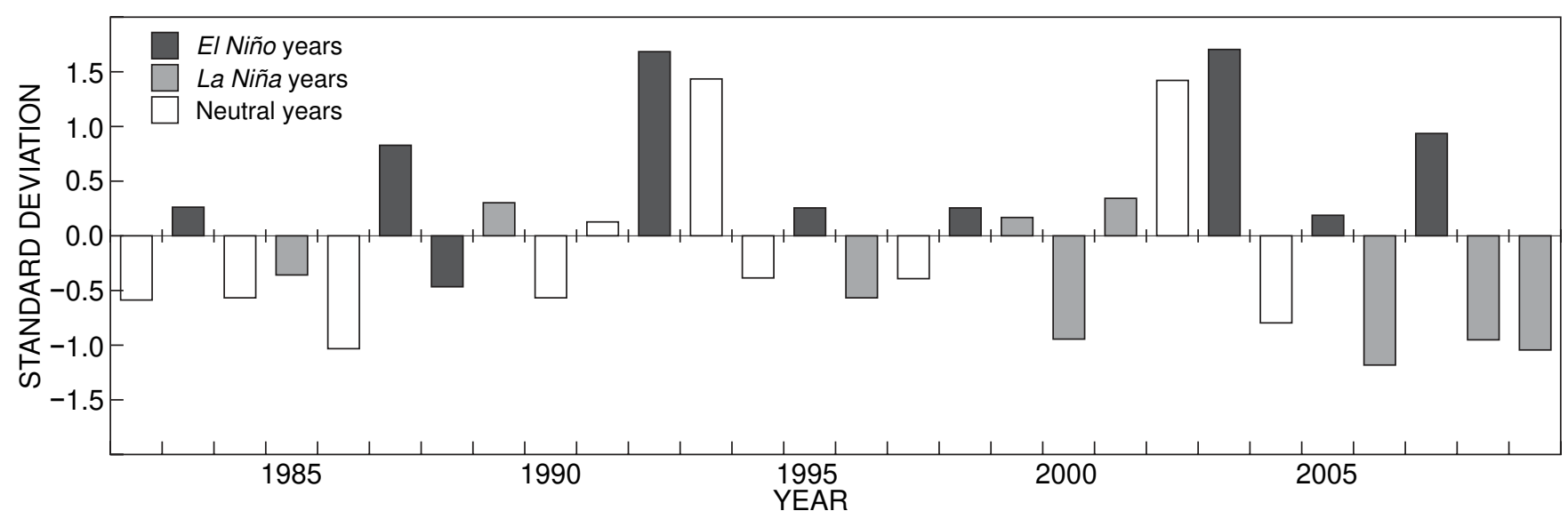

Figure 6: Detrended normalised anomalies from the mean of February, March and April from 1982 to 2008 for the West Coast domain, indicating the correlation between cold and warm events and La Niña and El Niño years

between ENSO strength and the strength of the climatic perturbation, and also that the ENSO sometimes does not affect the region. This actually reduces the value of the correlation between ENSO and SST or rainfall. The relationship between coastal wind and the ENSO is illustrated in Figure 7. 

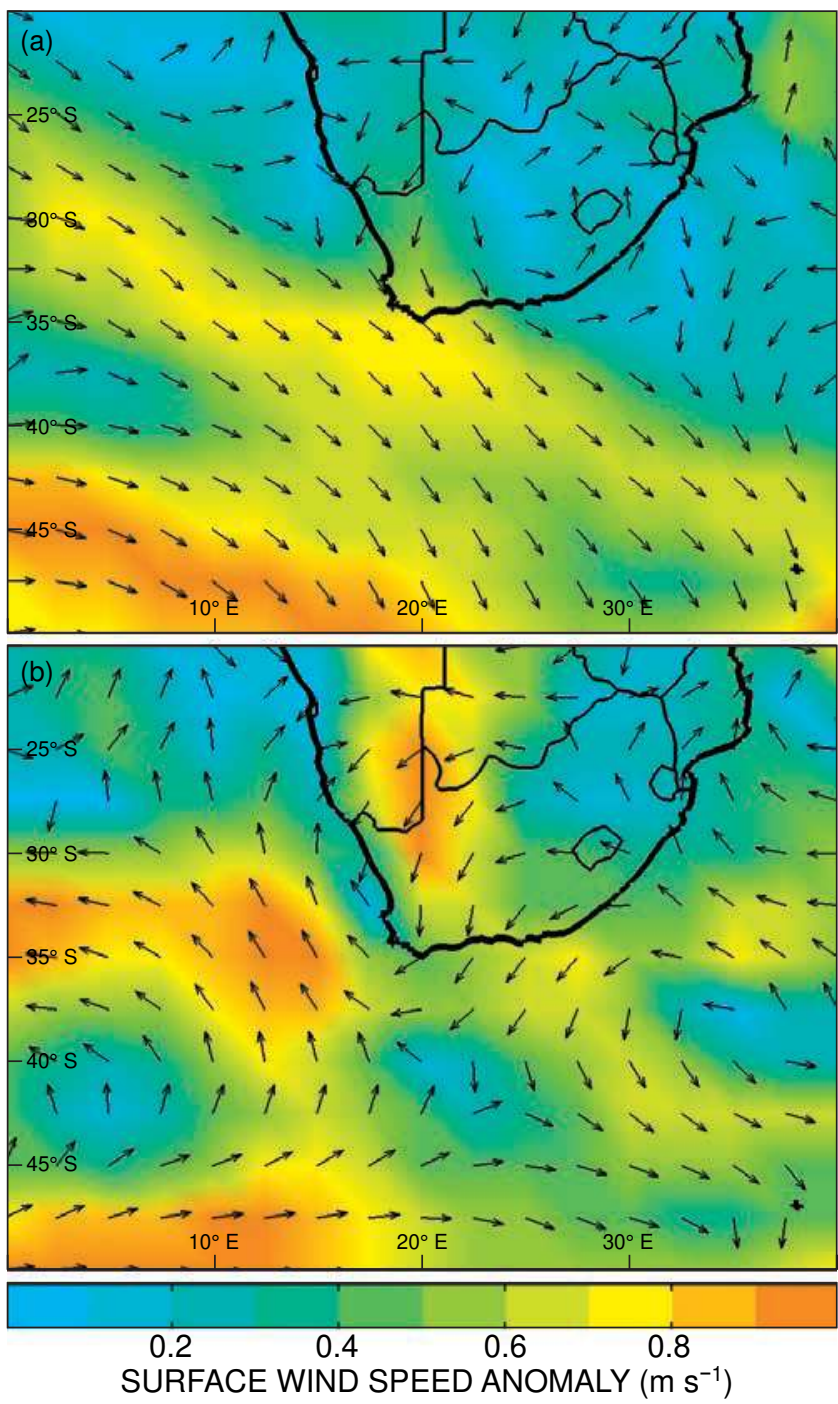

Figure 7: NCEP 1979-2008 surface mean summer direction (arrows) and wind speed anomaly from the mean summer condition for the average of six summers during (a) El Niño and (b) La Niña condition. Stronger (weaker) than normal easterly and south-easterly winds prevail during La Niña (El Niño)

Figure 7 is a composite of surface wind speed vector anomalies during La Niña and El Niño in the austral summer. The composites were constructed by averaging the $2.5^{\circ} \times$ $2.5^{\circ}$ resolution NCEP surface wind speed for seven El Niño and seven La Niña events in January, February and March, and subtracting the equivalent climatological mean at the same time of year from 1979 to 2008. El Niño years are 1983, 1987, 1988, 1992, 1995, 2003 and 2007, and La Niña years are 1985, 1989, 1996 1999, 2000, 2006 and 2008. Mean wind speed along the coasts of South Africa at that time of year is south-easterly along the West Coast and easterly along the South Coast. A north-westerly anomaly means that wind speed is weaker than normal and a southeasterly anomaly that the wind is stronger than normal. Although the resolution of the wind data is not totally able to describe coastal wind speed, weaker (stronger) upwellingfavourable wind is present during El Niño (La Niña), and this

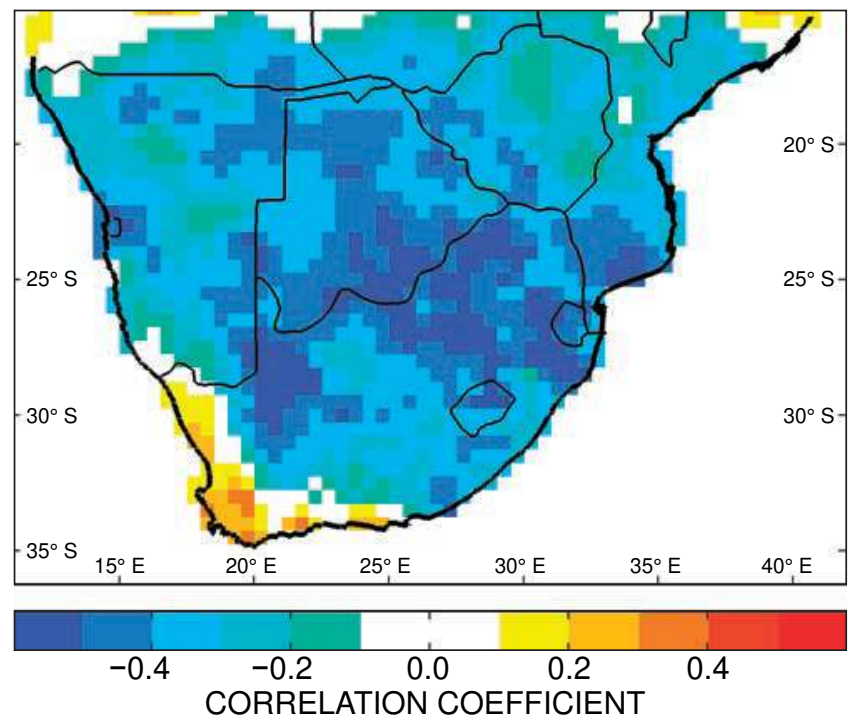

Figure 8: Correlation between the late austral summer (mean of March and April) GPCC rainfall-normalised anomaly and the West Coast SST-normalised anomaly, 1982-2007

explains the SST anomaly during ENSO. This pattern is due to a change in large-scale atmospheric circulation during El Niño or La Niña (Richard et al. 2000, 2001, Colberg et al. 2004, Fauchereau et al. 2003, 2009, Pohl et al. 2009). Figure 8 shows the correlation between the mean of March and April rainfall-normalised anomalies and the West Coast normalised SST from 1982 to 2007. Rainfall was obtained from the $1^{\circ} \times 1^{\circ}$ resolution GPCC (Schneider et al. 2008) dataset derived from land observations. The correlation between rainfall anomaly and SST anomaly is negative and plotted for values between 0.6 and 0.4. Cooler (warmer) than normal SST at the West Coast is recorded when rainfall is above (below) normal inland, and vice versa. When rainfall is greater than normal, this favours lower atmospheric pressure above the continent and increases the pressure gradient between the continent and the ocean, so increasing upwelling-favourable wind. The opposite happens when rainfall is lower than normal and higher than normal pressure is above the continent. This could add to the effect of largescale perturbation in atmospheric circulation associated with the ENSO.

Correlation between the AAO Index and SST anomalies for the six regions defined are presented for all months of the year in Figure 9. The AAO index is obtained as the leading principal component of an extended orthogonal function (EOF) analysis applied to the $700 \mathrm{hPa}$ geopotential height anomaly field south of $20^{\circ} \mathrm{S}$, after removal of the annual cycle, and for the period 1979-2006. Each grid point was previously scaled by the square root of the cosine of its latitude. A positive (negative) phase of the AAO index corresponds to above- (below-) average surface pressure over the Southern Ocean and below- (above-) average pressure over Antarctica. The correlations between the AAO and the SST time-series is less coherent than that found for the ENSO. The absence of coherent correlation between the AAO and the Agulhas Current system, especially in winter, questions the validity of the influence of the AAO 


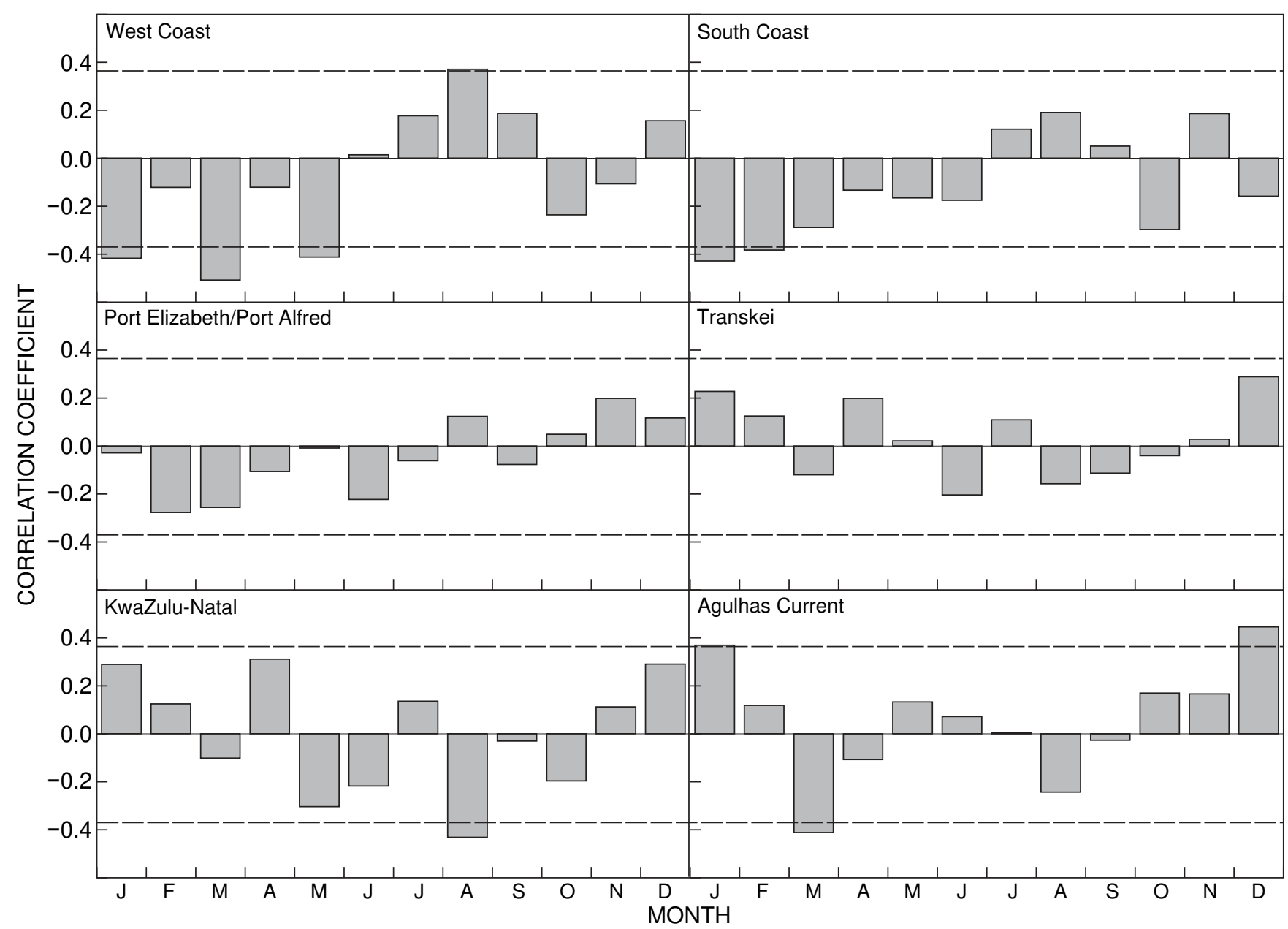

Figure 9: Correlation between the AAO index and Reynolds SST normalised anomalies for the West Coast, South Coast, Port Elizabeth/Port Alfred, Transkei, KwaZulu-Natal and the Agulhas Current system ( $\left.36^{\circ}-42^{\circ} \mathrm{S}, 10^{\circ}-35^{\circ} \mathrm{E}\right)$. Statistically significant correlations are marked with dashed lines

on the region at an interannual scale. West Coast SST is correlated with a positive phase of the AAO in winter. The correlation is less significant for the South Coast and absent for Port Elizabeth/Port Alfred. The correlation in summer is to be recorded with caution. A recent study (Pohl et al. 2010) shows that the significance of the teleconnections between South African rainfall in summer and the AAO is a statistical artefact and weaker once the influence of the ENSO is removed. Indeed, partial correlations between the AAO and SST anomalies with the ENSO effect removed for the six regions in a similar fashion as done by Pohl et al. (2010) further reduce the former correlation (data not shown).

Figure 10 shows the linear trend in NCEP surface wind speed in the region from 1982 to 2009. ERA40 data are only available up to 2001, but show similar trends (supplementary material in Rouault et al. 2009) of surface wind speed increasing in the South Atlantic and Indian Ocean subtropics. It is a consequence of an increase in sea level pressure in both the South Atlantic and the South Indian oceans (supplementary material in Rouault et al. 2009). The observed change in sea level pressure and wind speed is consistent with a poleward shift of the westerly wind in the
Southern Hemisphere and an increase in the South Atlantic and South Indian Ocean high pressure systems described by others (Thompson and Solomon 2002, Gillett et al. 2003, Chen and Held 2007, Seidel et al. 2008).

\section{Discussion and conclusions}

Caution needs to be exercised when using ERA40 or NCEP data at a regional scale for calculating the trend. For instance, ERA40 data show a decrease in wind speed off Angola and Namibia (supplementary material in Rouault et al. 2009), whereas NCEP data show an increase (Figure 10). There is up to a $20 \%$ difference between climatological mean regional surface wind speed data between ERA40 and the NCEP for the same period of 1979-2001 (data not shown), for instance for Angola and for the Southern Ocean. Another caveat to interpretation is that small oceanic features are not present in the Reynolds SST because of its resolution, the interpolation scheme used and the utilisation of AVHRR not allowing sampling in cloudy conditions or in conditions of intense glare from the sun. The core of the Agulhas Current is not present (Rouault et al. 2003a), and 


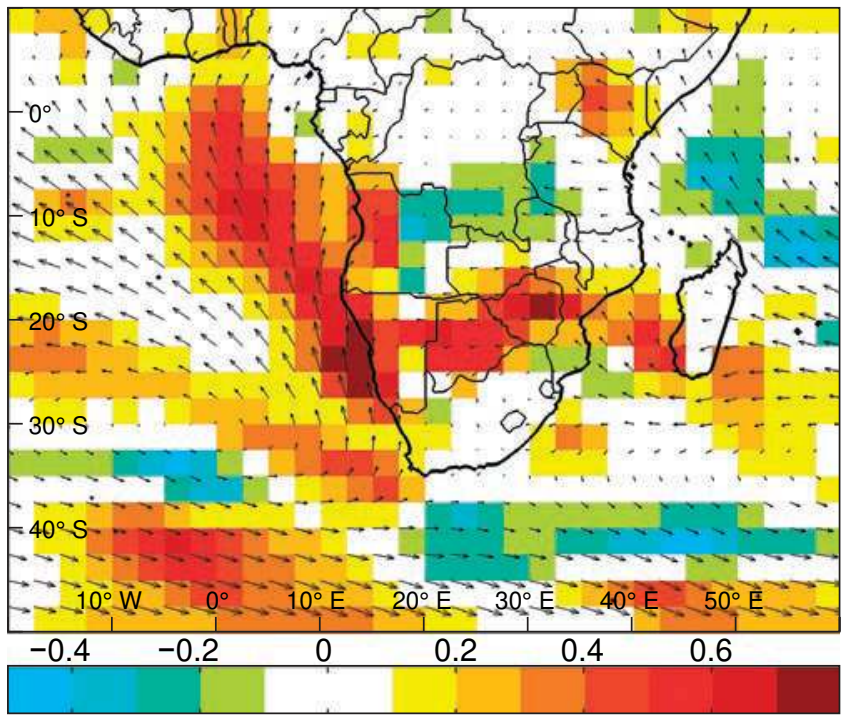

SURFACE WIND SPEED TREND ( $\mathrm{m} \mathrm{s}^{-1}$ per decade)

Figure 10: NCEP 1982-2009 linear trend in surface wind speed superimposed with the climatological mean direction (arrows)

neither the Port Alfred upwelling cell nor the Namaqualand and Cape Columbine upwelling cell are well defined in the Reynolds SST. The Reynolds SST has also a spurious coastal gradient from east to west. For small domains such as the upwelling cell off Port Alfred or in the vicinity of the Agulhas Current, therefore the Reynolds SST should be applied with caution. Because of the interpolation scheme, each $1^{\circ}$ resolution cell is liable to influence other cells.

The most obvious change in the region is the warming of the Agulhas Current system as a consequence of intensification of the Agulhas Current system. Warming is stronger to the west of the domain defined here. The West Coast and the South Coast show a wind-related cooling pattern from January to August that seems to be triggered by intensification of the high pressure system in the South Atlantic. There is also cooling in the Port Elizabeth/Port Alfred system that could be caused by a combination of increased upwelling-favourable wind and intensification of the Agulhas Current. Clearly, however, the ENSO appears to be an important driver of interannual variability in SST in austral summer and autumn.

Acknowledgements - Funding for this work was provided by WRC, ACCESS, NRF, IRD, Nansen-Tutu Center and CNRS (PICS PESOCA), and we thank Aviso, NOAA, UKMO, ECMWF and NCEP for data. This manuscript is a contribution to the SEACHANGE NRF programme, the ACCESS climate programme and the ACDI programme.

\section{References}

Agenbag JJ. 1996. Pacific ENSO events reflected in meteorological and oceanographic perturbations in the southern Benguela system. South African Journal of Science 92: 243-247.

Allan RJ, Reason CJC, Lindesay JA, Ansell TJ. 2003. Protracted ENSO episodes over the Indian Ocean region. Deep-Sea Research I/ 50: 2331-2347.
Chen G, Held IM. 2007. Phase speed spectra and the recent poleward shift of Southern Hemisphere surface westerlies. Geophysical Research Letters 34: L21805, doi:10.1029/2007GL031200.

Colberg F, Reason CJC, Rodgers K. 2004. South Atlantic response to ENSO induced climate variability in an OGCM. Journal of Geophysical Research 109: C12015, doi 10.1029/2004JC002301.

Crépon M, Richez C. 1982. Transient upwelling generated by two-dimensional atmospheric forcing and variability in the coastline. Journal of Physical Oceanography 12: 1437-1457.

Fauchereau N, Pohl B, Reason CJC, Rouault M, Richard Y. 2009. Recurrent daily OLR patterns in the Southern Africa/Southwest Indian Ocean region, implications for South African rainfall and teleconnections. Climate Dynamics 32: 575-591.

Fauchereau N, Trzaska S, Rouault M, Richard Y. 2003. Rainfall variability and changes in southern Africa during the 20th century in the global warming context. Natural Hazards 29: 139-154.

Gillett NP, Zwiers FW, Weaver AJ, Stott PA. 2003. Detection of human influence on sea-level pressure. Nature 422: 292-294.

IPCC. 2007. Climate change 2007. The physical science basis. In: Solomon S, Qin D, Manning M, Chen Z, Marquis M, Avery KB, Tignor M, Miller HL (eds), Contribution of Working Group I to the fourth assessment report of the Intergovernmental Panel on Climate Change. Cambridge: Cambridge University Press.

Kalnay E, Kanamitsu M, Kistler R, Collins W, Deaven D, Gandin L, Iredell M, Saha S, White G, Woollen J, Zhu Y, Leetmaa A, Reynolds R, Chelliah M, Ebisuzaki W, Higgins W, Janowiak J, Mo KC, Ropelewski C, Wang J, Jenne R, Joseph D. 1996: The NCEP/NCAR, 40-year reanalysis project. Bulletin of the American Meteorology Society 77: 437-471.

Penven P, Lutjeharms JRE, Florenchie P. 2006. Madagascar: a pacemaker for the Agulhas Current system? Geophysical Research Letters 33: L17609, doi:10.1029/2006GL026854.

Pohl B, Fauchereau N, Reason CJC, Rouault M. 2010. Relationships between the Antarctic Oscillation, the Madden-Julian Oscillation and ENSO, and consequences for rainfall analysis. Journal of Climate 23: 238-254.

Pohl B, Fauchereau N, Richard Y, Rouault M, Reason CJC. 2009 Interactions between synoptic, intraseasonal and interannual convective variability over southern Africa. Climate Dynamics 33: 1033-1050.

Reason CJC, Engelbrecht F, Landman WA, Lutjeharms JRE, Piketh S, Rautenbach H, Hewitson BC. 2006. A review of South African research in atmospheric science and physical oceanography during 2000-2005. South African Journal of Science 102: 35-50.

Reason CJC, Rouault M. 2005. Links between the Antarctic Oscillation and winter rainfall over southwestern South Africa. Geophysical Research Letters 32: L07705, doi:10.1029/2005GL022419.

Reynolds RW, Rayner NA, Smith TM, Stokes DC, Wang W. 2002. An improved in situ and satellite SST analysis for climate. Journal of Climate 15: 1609-1625.

Richard Y, Fauchereau N, Poccard I, Rouault M. 2001. 20th century droughts in southern Africa: spatial and temporal variability, teleconnections with oceanic and atmospheric conditions. International Journal of Climatology 21: 873-885.

Richard Y, Trzaska S, Roucou P, Rouault M. 2000. Modification of the southern African rainfall variability/ENSO relationship since the late 1960s. Climate Dynamics 16: 883-895.

Rio MH, Schaeffer P, Hernandez F, Lemoine J-M. 2005. The estimation of the ocean Mean Dynamic Topography through the combination of altimetric data, in-situ measurements and GRACE geoid: from global to regional studies. Paper presented at GOCINA International Workshop, European Space Agency, Luxembourg.

Rouault M, Florenchie P, Fauchereau N, Reason CJC. 2003a. South east Atlantic warm events and southern African rainfall. Geophysical Research Letters 30: 8009, doi:10.1029/2002GL014840.

Rouault M, Lee-Thorp AM, Ansorge I, Lutjeharms JRE. 1995. The 
Agulhas Current Air-Sea Exchange Experiment. South African Journal of Science 91: 493-496.

Rouault M, Lee-Thorp AM, Lutjeharms JRE. 2000. Observations of the atmospheric boundary layer above the Agulhas Current during along current winds. Journal of Physical Oceanography 30: 70-85.

Rouault M, Lutjeharms JRE. 2003. Microwave satellite remote sensing of SST around southern Africa. South African Journal of Science 99: 489-494.

Rouault M, Melice JL, Reason CJC, Lutjeharms JRE. 2005. Climate variability at Marion Island, Southern Ocean, since 1960. Journal of Geophysical Research 110: C05007, doi: 10.1029/ 2004JC002492.

Rouault M, Penven P, Pohl B. 2009. Warming of the Agulhas Current since the 1980s. Geophysical Research Letters 36: L12602, doi:10.1029/2009GL037987.

Rouault M, Reason CJC, Lutjeharms JRE, Beljaars A. 2003b. NCEP Reanalysis and ECMWF operational model underestimation of latent and sensible heat fluxes above the Agulhas Current. Journal of Climate 16: 776-782.

Rouault M, Richard Y. 2003. Spatial extension and intensity of droughts since 1922 in South Africa. Water SA 29: 489-500.

Rouault M, Richard Y. 2005. Intensity and spatial extent of droughts in Southern Africa. Geophysical Research Letters 32: L15702, doi:10.1029/2005GL022436.
Roy C, Weeks S, Rouault M, Nelson G, Barlow R, van der Lingen C. 2001. Extreme oceanographic events recorded in the southern Benguela during the 1999-2000 summer season. South African Journal of Science 97: 455-460.

Schneider U, Fuchs T, Meyer-Christoffer A, Rudolf B. 2008. Global precipitation analysis products of the GPCC. Offenbach: Global Precipitation Climatology Centre (GPCC), Deutscher Wetterdienst (DWD). Available at ftp://ftp-anon.dwd.de/pub/data/gpcc/PDF/ GPCC_intro_products_2008.pdf [accessed August 2010].

Seidel DJ, Fu Q, Randel WJ, Reichler TJ. 2008. Widening of the tropical belt in a changing climate. Nature Geoscience 1: 21-24.

Thompson DWJ, Solomon S. 2002. Interpretation of recent southern hemisphere climate change. Science 296: 895-899.

Thompson D[WJ], Wallace J. 2000. Annular modes in the extratropical circulation. 1. Month-to-month variability. Journal of Climate 13: 1000-1016.

Trenberth KE. 1990. Recent observed interdecadal climate changes in the northern hemisphere. Bulletin of the American Meteorological Society 71: 988-993.

Wolter K, Timlin MS. 1993. Monitoring ENSO in COADS with a seasonally adjusted principal component index. In: Proceedings of the 17th climate diagnostics workshop. Norman, Oklahoma: NOAA/NMC/CAC, NSSL, Oklahoma Climate Survey, CIMMS and the School of Meteorology, University of Oklahoma. pp 52-57. 